\title{
Vibration of Thin Walls during Cutting Process of 7075 T651 Aluminium Alloy
}

\author{
Jerzy Józwik ${ }^{1}$, Dariusz Mika², Krzysztof Dziedzic ${ }^{3}$ \\ ${ }^{1}$ Department of Production Engineering, Mechanical Engineering Faculty, Lublin University of Technology, 36Nadby- \\ strzycka Street, 20-816 Lublin, Poland, e-mail: j.jozwik@ pollub.pl \\ ${ }^{2}$ The State School of Higher Education, The Institute of Technical Sciences and Aviation, 54Pocztowa Street, 22-100 \\ Chełm, Poland, e-mail: dmika@pwsz.chelm.pl \\ ${ }^{3}$ Fundamentals of Technology Faculty, Lublin University of Technology, 38Nadbystrzycka Street, 20-618 Lublin, Poland, \\ e-mail: k.dziedzic@pollub.pl
}

The subject of this study is the analysis of vibrations induced during milling of a thin-walled element. The milling was performed with a 2 -flute custom end mill for machining Al alloys (FENES, $12 \times 22 \times 80-45^{\circ} \mathrm{W}-\mathrm{Z2}$ ), diameter $\mathrm{d}=12 \mathrm{~mm}$. The rectangular 7075-T651 aluminium alloy workpiece of the following original dimensions: 120x60x12, was machined in a DMG MORI DMU 65 MonoBLOCK 5-axis milling machine. The vibrations of the aluminium alloy test plate were identified with Siemens LMS Scadas Mobile system and LMS Test Lab software. A PCB Piezotronics triaxial ICP accelerometer (model 356B21), offering sensitivity of 10mV/g, was employed. The sampling frequency was $11.5 \mathrm{kHz}$. The first stage consisted in measuring the vibration levels of the sample, in the function of its thickness and federate $v_{f}$, at constant technological parameters of machining. The feed $v_{f}$ was set to $1500,2000,2500$ and $3000 \mathrm{~mm} / \mathrm{min}$, the depth of cut $a_{p}=2 \mathrm{~mm}$, the cutting speed was constant and equal to $v_{c}=$ $150.7 \mathrm{~m} / \mathrm{min}$ (n=4000rev/min). The wall thickness $b$ of samples was equal to: $30 \mathrm{~mm}$ - reference sample and 11, 9 , $7,5,3 \mathrm{~mm}$ - test samples. The vibration signal was measured by two sensors attached to the surface of the sample in two extreme positions on the sample: point $\mathrm{P} 1$ and point $\mathrm{P2}$.

Keywords: Cutting Process, Aluminium Alloy, Vibration, Chatter, Thin-Walls

\section{References}

[1] GALEWSKI, M. (2007). Nadzorowanie drgań podczas frezowania szybkościowego smukłymi narzędziami z wykorzystaniem zmiennej prędkości obrotowej wrzeciona. In: Rozprawa doktorska, Gdańsk.

[2] JÓZWIK, J., KOBYŁKA, M. (2011). Badanie wpływu parametrów geometrycznych kieszeni prostokątnej oraz warunków realizacji procesu skrawania na drgania podczas frezowania trochoidalnego. In: Postępy Nauki i Techniki / Advances in Science and Technology, No 8, pp. 37-44. Lublin.

[3] JEMIELNIAK, K., WYPYSIŃSKI, R. (2013). Symulacja numeryczna drgań samowzbudnych - przegląd metod, możliwości i potencjalnych korzyści. In: Mechanik, No 8-9, suplement - wersja elektroniczna, pp. 43-56, Warszawa.

[4] JÓZWIK, J. (2011). Modelowanie ugięć sprężystych przedmiotów obrabianych w procesie skrawania toczeniem. In: Postepy Nauki i Techniki/Advances in Science and Technology, nr 8, pp.183-191. Lublin.

[5] JÓZWIK, J. (2014). Analiza ruchu podczas obróbki frezarskiej przedmiotów cienkościennych z zastosowaniem wizyjnego systemu pomiarowego 3D. In: Mechanik, No 8-9, pp. 551-562. Warszawa.

[6] JÓZWIK, J., FILIPIAK, P. (2009). Analysis of feedrate correction influence on corner radius errors of workpieces during milling. In: Journal of Machine Engineering, vol. 9, No 1, 66-77.

[7] KECIK, K., RUSINEK, R., WARMINSKI, J. (2013). Modelling of high-speed milling process with frictional effect. In: Journal of Muti-body Dynamics, Proceedings of the Institution of Mechanical Engineers, Part K, vol.1(1), pp. 3-11.

[8] KUCZMASZEWSKI, J., PIEŚKO, P. (2014). Wear of milling cutters resulting from high silicon aluminium alloy cast AISi21 CuNi machining. In: Maintenance and Reliability, No 1, vol. 16, 37-41, Warszawa.

[9] KUCZMASZEWSKI, J., Zaleski, K. (2015). Obróbka skrawaniem stopów aluminium i magnezu, Politechnika Lubelska. Lublin.

[10]MÜlLER, M., LEBEDEV, A., SVOBODOVÁ, J., NÁPRSKOVÁ, N., LEBEDEV, P. (2014). Abrasive-free U1trasonic Finishing of Metals. In: Manufacturing Technology, Vol. 14, No. 3, ISSN 1213-2489. Usti nad Labem.

[11]Müller, M. (2015). Research on Constructional Shape of Bond at Connecting Galvanized Sheet of Metal. In: Manufacturing Technology, Vol. 15, No. 3, ISSN 1213-2489. Usti nad Labem.

[12]RUSINEK, R. (2010). Vibrations In Cutting Process Of Titanium Alloy. In: Maintenance and Reliability, No 3 , pp. 48-55. Warszawa. 
[13]RUSINEK, R. WARMIŃSKI, J., SZABELSKI, K. (2006). Drgania nieliniowe w procesie skrawania toczeniem. In: Monografia. IZT Sp.z. o., Lublin.

[14]SŁODKI, B., ZĘBALA, W. (2009). Stanowisko do rejestracji obrazów szybkozmiennych w procesach skrawania. In: Obróbka skrawaniem zaawansowana technika pod redakcją Huberta Latosia, Wydawnictwo Uczelniane Uniwersytetu Technologiczno - Przyrodniczego, pp. 215-220. Bydgoszcz,

[15]SVOBOdOVÁ, J, KRAUS, P., MÜLlER, M., LEBEDEV, A., YUROV, A., LEBEDEV, P. (2015). Influence of Cutting Fluid on Abrasive - Free Ultrasonic Finishing of Aluminium Alloy. In: Manufacturing Technology, Vol. 15, No 4, ISSN 1213-2489. Usti nad Labem.

[16]CHRUŚCIELSKI, G. (2012). Wpływ anizotropii po walcowaniu na odporność na pękanie materiału AW 7075 T651. In: Postępy Nauki i Techniki / Advances in Science and Technology, No 12, pp. 19-27. Lublin.

Copyright $\odot$ 2016. Published by Manufacturing Technology. All rights reserved. 